WORKING PAPERS OF THE

CENTER FOR RESEARCH ON SOCIAL ORGANIZATION

DEPARTMENT OF SOCIOLOGY

UNIVERSITY OF MICHIGAN

Copies Available Through:

Paper \#40 (Revised Edition)

Center for Research on Social Organization

September, 1968 University of Michigan

219 Perry Building

330 Packard Street

Ann Arbor, Michigan 48104 


\section{THE SOCIAL ORGANIZATION OF LEGAL CONTACTS*}

by

Leon Mayhew and Albert J. Reiss, Jr.

Center for Research on Social Organization University of Michigan

* Being a revised edition of a paper presented at the annual meetings of the Midwest Sociological Association, Omaha, INebraska, April 19, 1968. 


\section{ABSTRACT}

This is a study of how both the organization of the legal system and of citizen affairs leads citizens to define affairs as legal matters and to seek advice from a lawyer. The data are from a sample survey of the problems and legal experiences of 780 residents of the Detroit Metropolitan Area, 604 white and 176 Negro. The findings show that income and location in the social structure affect citizen contacts with attorneys not only by providing relevant resources but by determining their types of problems. Each type of problem has its own pattern of requirements and constraints for the use of legal services, The type of problem, institutionalized definitions about it, available resources, and the social organization of problem solution engender contacts. with the legal profession. 


\section{THE SOCIAL ORGANIZATION OF - LEGAL CONTACTS}

Everyone from time to time defines his affairs as legal matters or experiences violations of his legal rights. Yet little is known of how citizen affairs come to the attention of attorneys or official legal agencies. Particularly lacking is an understanding of how both the organization of citizen affairs and of the legal system leads citizens to define affairs as legal matters and to seek advice from a lawyer. This paper presents some findings on problems citizens define as legal matters and their contact with. attorneys.

To prevent confusion and to forestall inappropriate criticism, we should also stress what the study is not. It is not, as are a number of recent studies, an attempt to assess the 'objective' legal requirements of a population from a value or organized system perspective: Nor is it an attempt to evaluate the quality of legal services. Rather it is based entirely on citizen reports of perceived problems and of their actual experience in problem solving, including contact with lawyers.

The findings result from a sample survey of the problems and legal experiences of 780 residents of the Detroit Metropolitan Area, 604 white and 176 Negro. The probability of selecting a Detroit City resident was set at twice that of a resident outside the central city so as to insure the inclusion of more Negro citizens in partial analyses. All 
estimates of proportions, therefore, are based on a weighted sample of 1,038 residents.

\section{The Prevalence of Seeking Legal Advice or Help}

Each resident was asked whether he had ever gone to a lawyer or talked with a lawyer in order to get help or advice on problems that can be legal matters. Approximately 7 of every 10. residents in the weighted sample report seeing a lawyer at least once about a legal matter. One in four reported seeing a lawyer in the last five years. The actual hiring of lawyers is overestimated somewhat by these proportions, since after seeing a lawyer some citizens decided they did not want or could not afford legal services.

Contact with lawyers is nevertheless a prevalent experience among Detroit area residents. Indeed, inspection of Table 1 shows that for all major race, sex, age, and socioeconomic status groups, contact with attorneys is higher than is commonly supposed. In the socioeconomic status group with least contact with attorneys--Negro females with a family income of less than $\$ 7,000$ a year--40 per cent reported seeing a lawyer about a legal problem.

Despite the high prevalence of contact with lawyers for all structural status groups shown in Table 1 , contact with a lawyer does vary with status. It might be objected that ever having seen a lawyer is a very weak index of legal contact since one visit to an attorney places a person among the "haves" but within our sample stronger indicators of 
legal contact such as seeing a lawyer about three or more separate types of incidents does not increase the difference in the legal experience of socioeconomic status groups. The best predictors of contact with attorneys are family income and property ownership as is indicated by the consistent and substantial differences among classes of income and home ownership, even when race and sex are controlled. Among respondents with annual family income of over $\$ 15,000,83$ per cent reported seeing a lawyer as compared to 56 per cent among persons with an income of less than $\$ 7,000$. Education, occupational status, age, and sex have a moderate to strong effect but none is as discriminating as family income or home ownership.

It might be supposed that the full relation between income and legal contact is being suppressed by the fact that we are comparing lifetime legal experience to family income during the year immediately preceding the study. Many older respondents may have visited lawyers only in. earlier years when they had more income. Though plausible, this objection is not well founded. Twenty-six per cent of all those who had ever visited a lawyer were in the lowest income group. Twenty-four per cent of those who visited a lawyer within the previous year were in the same low income group.

On first glance race appears to have a substantial effect on seeking legal services. Fifty-nine per cent of Negroes and 71 per cent of whites said they saw a lawyer 
about a legal matter. Closer scrutiny indicates that this difference is largely accounted for by the asymmetric position of Negro females who saw lawyers less frequently than either ivegro males or white females. Negro males, despite the facts of low income and education, report nearly as much contact with attorneys as their white counterparts. On the other hand, Negro males are also more likely to report that they have been "cooled out" during a visit to an attorney. Seventeen per cent of Negro males said that they had been discouraged from taking legal action by an attorney. The comparable figure for white males is only 7 per cent. These socioeconomic differences in the use of legal services are consistent.with differences found in studies of other cities. (Carlin and Howard, 1965: 382-383). I/

\section{Social Organization and Contact with Attorneys}

Previous studies of this type have regularly shown a strong relation between income and the use of professional legal services. Income differences are then attributed to the fact that the poor cannot afford legal representation, that they are unaware of legal problems and services, and that they distrust attorneys. (Carlin and Howard, 1965: 381-382, 423-429). This view can be described as a "resources" theory of legal representation. Those who have resources such as income, and to a lesser extent other resources such as education, confidence, and social connections, are more likely to perceive the need.for, afford, and 
gain access to legal services. Resources, therefore, account for the distribution of the use of lawyers in the population. That resources make a difference is most clearly supported by the association between income and using attorneys within populations who have experienced a given legal problem. Conard, et al. (1964: 225-227), for example, report a positive association between income and legal representation among a sample of persons who have been injured in automobile accidents.

Nevertheless, the resources theory fails to account for the extent of use of legal services even among those. with the least resources. More seriously, the resources theory fails to predict the differences in patterns of use of legal services across socioeconomic categories. Access to resources is not a sufficient explanation of the patterns of contact between attorneys and the public, for attorney-client relations occur in the context of a complicated network of social organization.

The resources theory appears to contemplate an approach to the use of legal machinery which echoes the doctrine of "economic man." There is a "litigious man" who weighs the costs of his problems against the costs of taking legal action and comes to a rational decision. In other contexts this has been shown. to be an inadequate basis for predictions about the use of legal agencies. (Mayhew, 1968a: 424-425). It is more important to know something about the character of routine organized activity within the legal agency, the social 
organization of the institutional arena subject to legal regulation. Out of the social links between these spheres flows a routine pattern of contact between the legal agency and the public. (Mayhew, 1968b: 152-198).

A parallel approach can be applied to the problem at hand. We know from a series of studies of the legal profession that legal practice is both specialized and stratified. The stratification of access to resources in the population parallels this differentiation and stratification of legal practice. The demand for legal services produces a response from competitive lawyers who move in to fill vacant niches so that distinctive patterns of practice emerge in various problem areas, e.g., estate, tax, criminal, contract, etc. (Carlin, 1962 and 1966). 2/ The response may be inadequate from the point of view of public policy but it is nonetheless a response. Specialization and stratification of legal practice accordingly mitigate the relation between resources and access to attorneys. We also observe a set of distinctive patterns of use of legal services which reflects variations in the patterns of problems experienced in various structural locations (such as by communities, or by race and ethnic groups), and corresponding differences in the social organization of legally relevant activity.

\section{Income and Property}

One important weakness of the resources theory is its failure to distinguish between resources as facilities and 
resources as constraints. The usual interpretation placed on the association between income and the use of legal services is that income enables the citizen to make use of legal services. Might the influence be more indirect? Income brings one into participation in the institution of property and property as an institution is socially organized so as to bring its participants into contact with attorneys. Anyone who has been caught up in the inescapable constraints of, say, a probate court is likely to agree. In other words, resources are not always enabling tools. Sometimes resources require the citizen to use legal services.

Our data support the proposition that a substantial portion of the income differential in contact with attorneys is accounted for by the greater participation of high income persons in the institution of property. Table 2 indicates that income differences in legal contact are considerably reduced when contact about matters other than property is considered alone. Although 69 per cent of our sample-had sought advice from attorneys, only 39 per cent had ever sought advice on matters other than property. The remaining 30 per cent had seen an attorney only about wills, estates, transactions in real estate, advice about entrepreneurial activity or business and property taxes and assessments. For nonproperty matters, that is domestic problems, neighborhood problems, automobile accidents, personal injuries, problems with public authority, and disputes about purchases and repairs of automobiles and other-expensive consumer goods, we find 
that persons with family incomes under $\$ 7,000$ still have the least contact with attorneys. Thirty-four per cent of this low income: group sought professional advice as compared with 42 per cent of the group with family incomes over $\$ 7,000$ but under $\$ 15,000$. However, this difference is considerably. smaller than the difference between these groups in total contact with attorneys. Further, beyond $\$ 7,000$, family income has no effect on contact with attorneys about nonproperty matters. Those with incomes over $\$ 15,000$ are more likely to seek legal help but only on matters relating to property.

In sum, the association between income and legal contacts is in part an organizational effect. The legal profession is organized to service business and property interests. The social organization of business and property is highly legalized. Out of the convergence between the organization of property emerges a pattern of citizen contact with attorneys heavily oriented to property

The dominance of property in the pattern of contact is evident in the fact that of our respondents' most recent consultation with attorneys three-fifths concerned property. Even for the lowest income group, those with family incomes under. $\$ 7,000$, one half had seen a lawyer most. recently about a property matter. 
Other Background Variables

More refined analyses of the various types of legal contact by social background variables show other examples of organizational effects on the pattern of legal contacts. These effects are shown in Tables 3 and 4. Although there is a rough similarity in the distribution of legal problems across all socioeconomic categories, a number of remarkable differences are also apparent.

One of the most striking differences is the racial variation in seeing lawyers about property matters, a fact reflecting the prevalence of home ownership in the Detroit area. Seventy-seven per cent of white respondents and 51 per cent of Negro respondents are home owners. Home ownership clearly has brought Negroes into contact with the legal profession; 36 per cent of Negroes have seen a lawyer about buying a home, a figure virtually identical to the 37 per cent of whites who have seen a lawyer for this purpose. But the introduction of iNegroes to the property: complex through home ownership has not yet become sufficiently institutionalized to incorporate Negroes fully. into the organized system for the transmission property. Only 3 per cent of Negroes had seen a lawyer about making a will. Among whites this is the second most common occasion for visiting a lawyer, with 23 per cent having seen a lawyer about making a will.

seeing a lawyer about a will is not viewed as a pressing legal problem among Negroes. In response to the query "Have 
you ever wanted to go to a lawyer but didn't for some reason?" Negroes and whites answered. "Yes". in approximately equal proportions, 19 per cent among whites and 17 per cent among Negroes. Yet only one Negro informant mentioned a will in this regard. In contrast, 35 per cent of the problems of whites who wanted to talk to a lawyer but did not involved wills. That the passing on of property is less embedded in a legal context among Negroes is also indicated from the fact that 20 per cent of whites and only 5 per cent of Negroes had seen a lawyer about settling an estate.

These differences by race status in the use of legal advice to handle personal property parallel rather closely the Negro's integration into American Society, Consider an institutionalized cycle of personal property where legal advice pertains first to its acquisition, then to its sale,. transformation, or taxation, then to advice on disposition in the event of the death of its owner, and finally to the settling of an estate. It seems clear that the Negro in major metropolitan areas such as Detroit is institutionally integrated in seeking legal. advice for the acquisition of personal property and has organized access to legal resources for that end. Given the recency of the acquisition, there is less integration with respect to other phases of the personal property cycle.

Nonetheless, given the high rate of acquisition of personal property among inegroes, particularly in the form of housing, one would forecast that Negroes will increasingly. 
seek legal advice for other property matters as well, although perhaps at a lesser rate. Some indication of this can be gained from the fact that the only Negroes in the sample to have seen a lawyer about making a will, were Negro males aged 55 and older. Twenty-six per cent of these Negro males as compared with 35 per cent of white females and 41 per cent of white males of this age group had seen a lawyer about making a will.

The incomplete involvement of Negroes in the property complex may also be related to the much noted fluidity of Negro family structure. This is suggested not only by the fact just cited--that only older Negro males make wills--but by the prevalence among Negroes of seeing lawyers about divorces, alimony, and child support. Among Negroes this type. of problem is the second most common occasion. for seeing a lawyer with 18 per cent having been to a lawyer in this connection. Among whites the problem ranks only seventh at 10 per cent.

It is worth noting in passing that this problem area of divorce, alimony, and child support is the only major area where the incidence of seeing a lawyer shows no relation to either income, occupational status, or education.

For all major categories of legal problems other than divorce and related matters, Negroes have had somewhat less contact with attorneys than whites. However, as mentioned before, Negro females account for much of the race difference. Comparing only Negro males to white males we find that Negro 
males are more likely to have seen a lawyer about buying, selling, or building a house, about advice in business matters, about traffic tickets, about disputes with employers and about divorce, alimony and child support although. Except in the case of divorce, however, the differences are quite small. In view of the fact that our Negro males have much less income: on the average than the white males, we can conclude that the Negro male participates in a number of organized systems that bring him into contact with lawyers more than might be expected on the basis of income. Looking at middle income $(\$ 7,000$ to $\$ 14,999)$ males, for example, we find that 23 per cent of Negroes and only 8 per cent of whites have seen a lawyer about a divorce or a related matter. On the other hand the greater proportion of whites who have seen a lawyer about making a will or settling an estate holds up even when income is introduced as a control. Looking only at low income males $(\$ 6,999$ and less), we find that 27 per cent of whites and 8 per cent of Negroes had seen a lawyer about a will and 10 per cent of whites and 8 per cent of Negroes had seen a lawyer about settling an estate. Among middle income males $(\$ 7,000$ to $\$ 14,999)$ the corresponding figures are 19 per cent of whites and 5 per cent of Negroes in regard to a will and 17 per cent of whites and 2 per cent of. Negroes in regard to settling an estate. In short, income. differences play a part in determining access to attorneys, but differences in patterns of participation in social organization, particularly the social organization of property and 
familial relations, also affect the patterns of contact between citizens and attorneys.

\section{Seeing A Lawyer: Rates and Incidence}

The preceding data refer primarily to the incidence of seeing lawyers about varioús types of legal problems. To compute a rate we would need to know what proportion of the sample had experienced a given type of legal problem and then what proportion of that group had seen a lawyer about it. In some contexts this is a less serious problem than in others. Thus, in a sense everyone has a problem in connection with making a will since, though some estates are small, everyone owns something and, though some are young, everyone will ultimately die. Further in some cases we have rough denominators for rates. Because we know who are now home owners, we are led to believe that the rate of consulting attorneys is higher for Negroes than whites. Holding sex and income constant, Negroes are as likely to have seen a lawyer about buying a home even though fewer Negroes are home owners. other matters such as accidents can be assumed to be relatively evenly distributed across socioeconomic categories. Nevertheless, in some categories, disputes with government agencies and tax problems for example, it is more difficult to estimate an appropriate denominator for computing a rate. The problem is exacerbated by the fact that the more one strives for comparability of problems through applying restrictive definitions to various types of problems, the 
smaller becomes the number of persons who have had that particular type of problem and, in some cases, the number who have seen a lawyer about that precise problem becomes too small to study.

At one point in our interview we attempted to generate case histories about the respondents most serious problems. First we took an inventory of the informants' problems in five areas--relations in the neighborhood, landlord-tenant relations, relations with the sellers of expensive objects, relations with public organizations, and discrimination because of race, sex, age, religion, nationality, or beliefs. Then we asked for detailed histories of the two problems which were considered by the respondent to have been the most serious or to have caused the most problems. For both most serious and second most serious problems considered separately about 9 per cent reported seeing a lawyer about the problem. Table 5 combines the most serious and second most serious problems and examines them by respondent!s race and sex, and by type of problem, indicating the per cent who saw a lawyer.

Few gross differences by race status are apparent. in Table 5. One difference merits brief attention since it illustrates differences that may emerge when rates rather than incidence is made the focus of study. Negroes are apparently more likely to visit lawyers when they face serious trouble with public organizations. The percentage who saw a lawyer among those, who chose problems with public 
organizations as one of their two most serious problems is 19. per cent for Negroes and 10 per cent for whites. Yet the corresponding incidence figures for seeing a lawyer about a problem with public organizations (including police) appears to be higher for whites than for Negroes. In other words, whites are more likely to see lawyers about problems in relation to government but Negroes appear to be more likely to see lawyers about their most serious problems with government authority. Beyond merely illustrating differences that emerge from variable ways of expressing degrees of contact with the legal profession, this difference reinforces an organizational interpretation of patterns of contact. Mere differences in access to resources cannot account for patterns of access to attorneys in regard to problems of public authority. Citizens at different income levels in different structural locations experience different types of problems and are connected to government in different ways. Accordingly they have different probabilities of becoming involved with attorneys in relations to government authority. Thus, Negro citizens report fewer difficult problems in relation to government but their serious problems with government are more likely to be with police and with welfare agencies and to require legal aid. White citizens report more problems with public organizations and more contact with attorneys about public organizations, but their worst problems concern taxes and government services rather than police and welfare agencies. Their most serious problems 
with public authority do not seem to have the same capacity to draw them into contact with attorneys.

In sum, income and location in the social structure may affect contact with attorneys not only through providing relevant resources but by determining what types of problems people have. Each problem has its own patterns of constraints and requirements for the use of legal services. Citizens are not brought into contact with the legal profession merely by their resources but by their problems, institutionalized definitions, and the social organization of problem solution.

\section{Conclusion}

The emphasis on the social organization of legal institutions as the source of patterns of contact between citizens and attorneys must be seen as a corrective to the common view that income in the form of funds to pay for legal representation is the crucial determinant of use of legal services. At the same time this argument must not be misconstrued as a reaffirmation of the view that the poor have no legal problems. This allegation is occasionally heard within the legal profession but the claim can hardly stand against the extensive documentation of the actual and potential legal problems of the poor. The poor have fewer legal problems only in the narrow sense that they have fewer problems that the legal profession habitually serves. 
The implication of our findings is that untreated problems exist for all segments of the community. Organized to serve property and a few other problems, notably divorces and accidents, the: legal profession provides relatively little professional representation and advice in relation to a broad panoply of problems surrounding such daily matters as the citizens relation to merchants or public authority. It cannot be said that such problems do not exist; our survey of citizen problems shows otherwise. But the institution of legal advocacy. is not organized to handle these problems on a routine basis. It is an interesting commentary on the legal frame of reference to note that one legal scholar has argued that such interests as rights to welfare benefits, job and retirement rights, and civil rights will only beadequately protected when lawyers come to see them as property rights.. (Reich, 1963).

One of our interviews provides a particularly telling example of the reach of the problem across social strata. One informant, himself a successful attorney, was rather contemptuous of the survey. He could not believe that our. standardized questions could apply to him since he had such ready access to legal services. Yet, in another section of the interview, this informant said that he had been cheated by a "gypsy" roofing contractor and that he had neither initiated legal action on the matter nor consulted anyone about such a possibility. This respondent was able to combine a comfortable sense of legal efficacy and a rather restricted 
concept of the limits of legal action.

Our findings suggest that those who advocate the extension of legal services through such devices as the neighborhood law office, group legal service, lay advocacy, and the ombudsman could well found their claim on failures beyond the denial of legal services to the poor. 
Table 1: Per Cent of All Residents who Sought Advice From A Lawyer by Social Background Factors: ' Weighted Sample of Detroit SMSA, 1967.

\begin{tabular}{|c|c|c|c|c|c|}
\hline $\begin{array}{l}\text { Social } \\
\text { Background } \\
\text { Factors }\end{array}$ & $\begin{array}{l}\text { Per Cent } \\
\text { Seeking } \\
\text { Advice } \\
\text { from Lawyer }\end{array}$ & $\begin{array}{l}\text { Social } \\
\text { Background } \\
\text { by Race } \\
\text { and Sex }\end{array}$ & $\begin{array}{c}\text { Per Cent } \\
\text { Seeking } \\
\text { Advice } \\
\text { from Lawyer }\end{array}$ & $\begin{array}{c}\text { Social } \\
\text { Background } \\
\text { by Race } \\
\text { and Sex }\end{array}$ & $\begin{array}{c}\text { Per Cent } \\
\text { Seeking } \\
\text { Advice } \\
\text { from Lawyer }\end{array}$ \\
\hline $\begin{array}{l}\text { Race: } \\
\text { White } \\
\text { Negro } \\
\text { Sex: } \\
\text { Male } \\
\text { Female } \\
\text { Race-Sex: } \\
\text { White male } \\
\text { White female } \\
\text { Negro male } \\
\text { Negro female } \\
\text { Home Ownership: } \\
\text { Owner } \\
\text { Renter } \\
\text { Religion: } \\
\text { Catholic } \\
\text { Protestant } \\
\text { Jewish }\end{array}$ & $\begin{array}{l}71 \\
59 \\
\\
\\
73 \\
66 \\
\\
\\
74 \\
69 \\
69 \\
53 \\
\\
\\
76 \\
52 \\
\\
\\
68 \\
70 \\
88\end{array}$ & $\begin{array}{l}\text { Race-Sex-Income: } \\
\text { White male } \\
\$ 6,999 \text { or less } \\
\$ 7,000-\$ 14,999 \\
\$ 15,000 \text { \& over } \\
\text { White female } \\
\$ 6,999 \text { or less } \\
\$ 7,000-\$ 14,999 \\
\$ 15,000 \text { \& over } \\
\text { Negro male } \\
\$ 6,999 \text { or less } \\
\$ 7,000-\$ 14,999 \\
\$ 15,000 \text { \& over } \\
\text { Negro female } \\
\$ 6,999 \text { or less } \\
\$ 7,000-\$ 14,999 \\
\$ 15,000 \text { \& over }\end{array}$ & $\begin{array}{r}59 \\
78 \\
84 \\
\\
61 \\
71 \\
83 \\
\\
58 \\
72 \\
\star \\
\\
40 \\
82 \\
\star\end{array}$ & $\begin{array}{l}\text { Race-Sex-Education: } \\
\text { White male } \\
\text { High school or less } \\
\text { Some college } \\
\text { White female } \\
\text { High school, or less } \\
\text { Some college } \\
\text { Negro male } \\
\text { High school or less } \\
\text { Some college } \\
\text { Negro female } \\
\text { High school or less } \\
\text { Some college }\end{array}$ & $\begin{array}{r}71 \\
82 \\
\\
67 \\
75 \\
\\
69 \\
\text { * } \\
52 \\
60\end{array}$ \\
\hline
\end{tabular}


Table 1: Per Cent of All Residents Who Sought Advice From A Lawyer by Social Background Factors: Weighted Sample of Detroit SMSA, 1967. (CONTINUED)

\begin{tabular}{|c|c|c|c|c|c|}
\hline $\begin{array}{l}\text { Social } \\
\text { Background } \\
\text { Factors }\end{array}$ & $\begin{array}{c}\text { Per Cent } \\
\text { Seeking } \\
\text { Advice } \\
\text { from Lawyer }\end{array}$ & $\begin{array}{l}\text { Social } \\
\text { Background } \\
\text { by Race } \\
\text { and Sex }\end{array}$ & $\begin{array}{c}\text { Per Cent } \\
\text { Seeking } \\
\text { Advice. } \\
\text { from Lawyer }\end{array}$ & $\begin{array}{c}\text { Social } \\
\text { Background } \\
\text { by Race } \\
\text { and Sex }\end{array}$ & $\begin{array}{c}\text { Per Cent } \\
\text { Seeking } \\
\text { Advice } \\
\text { from Lawyer }\end{array}$ \\
\hline 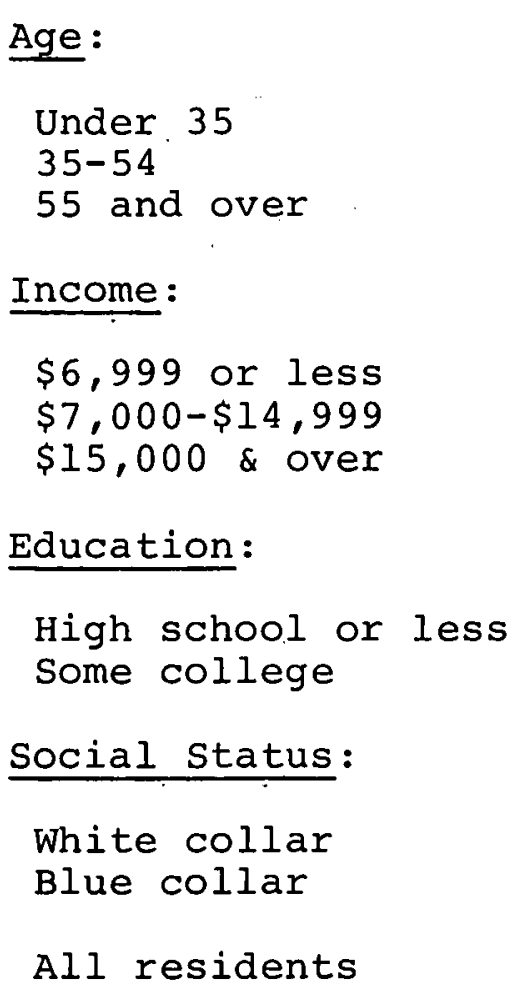 & $\begin{array}{l}65 \\
73 \\
69 \\
\\
\\
56 \\
74 \\
83\end{array}$ & $\begin{array}{l}\text { Race-Sex-Social } \\
\text { Status: } \\
\text { White male } \\
\text { White collar } \\
\text { Blue collar } \\
\text { White female } \\
\text { White collar } \\
\text { Blue collar } \\
\text { Negro male } \\
\text { White collar } \\
\text { Blue collar } \\
\text { Negro female } \\
\text { White collar } \\
\text { Blue collar }\end{array}$ & $\begin{array}{l}79 \\
70 \\
. \\
72 \\
67 \\
\\
77 \\
67 \\
\\
57 \\
52\end{array}$ & $\begin{array}{l}\text { Race-Sex-Home Owner- } \\
\text { ship: } \\
\text { White male } \\
\text { Owns } \\
\text { Rents } \\
\text { White female } \\
\text { Owns } \\
\text { Rents } \\
\text { Negro male } \\
\text { Owns } \\
\text { Rents } \\
\text { Negro female } \\
\text { Owns } \\
\text { Rents }\end{array}$ & $\begin{array}{l}77 \\
64 \\
\\
76 \\
46 \\
\\
72 \\
66 \\
\\
71 \\
36\end{array}$ \\
\hline
\end{tabular}


Table 2: Per Cent of All Residents Who Saw Lawyer About Property and Non-Property Matters, Lifetime and Last Visit to Lawyer by Family Income: Weighted Sample of Detroit SMSA, 1967.

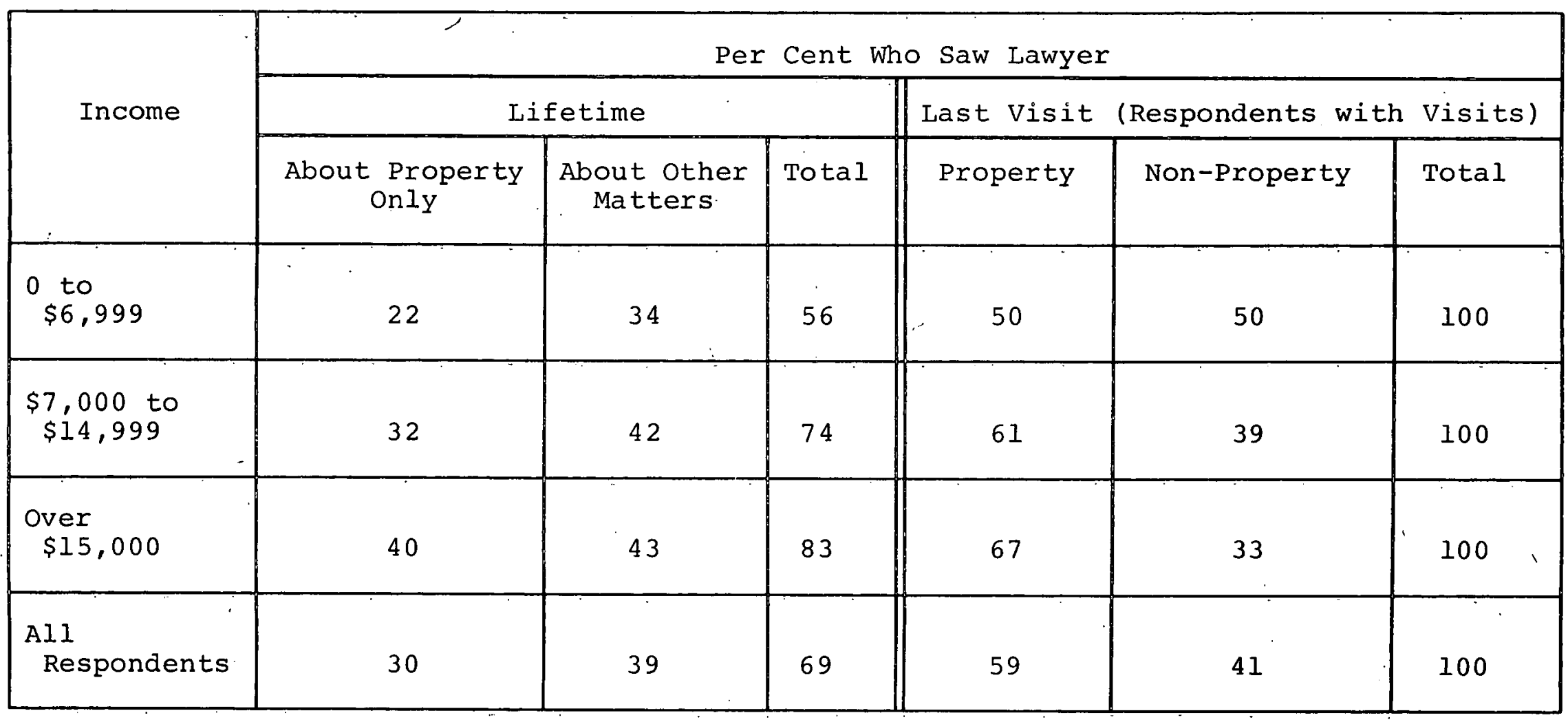


Table 3: Per Cent of All Residents Who Saw Lawyer by Fourteen. Types of Legal Problems and Rank Order of These Per Cents, by Race and Sex of Respondent: Weighted Sample of Detroit.SMSA, 1967.

\begin{tabular}{|c|c|c|c|c|c|c|c|c|c|c|}
\hline \multirow{3}{*}{ R Saw A Lawyer About: } & \multicolumn{4}{|c|}{ Per Cent of All R's } & \multicolumn{4}{|c|}{ Rank Order of \%'s } & \multicolumn{2}{|c|}{ Total } \\
\hline & \multicolumn{2}{|c|}{ White } & \multicolumn{2}{|c|}{ Negro } & \multicolumn{2}{|c|}{ White } & \multicolumn{2}{|c|}{ Negro } & \multirow{2}{*}{$\begin{array}{l}\text { Per } \\
\text { Cent }\end{array}$} & \multirow{2}{*}{$\begin{array}{l}\text { Rank } \\
\text { Order }\end{array}$} \\
\hline & $\mathrm{M}$ & $\mathrm{F}$ & M & $\mathrm{F}$ & M & $\mathrm{F}$ & M & $\mathrm{F}$ & & \\
\hline $\begin{array}{l}\text { Buying/selling/building a house } \\
\text { Making a will. } \\
\text { Settling an estate } \\
\text { Advice on business matters } \\
\text { Insurance claims } \\
\text { Divorce/alimony/child support } \\
\text { Contract disagreements } \\
\text { Tax problems/disputes with officials } \\
\text { Traffic tickets } \\
\text { Neighborhood } \\
\text { Accused of crime/disturbance } \\
\text { Domestic-family } \\
\text { Employer/employee disputes } \\
\text { Landlord-tenant }\end{array}$ & $\begin{array}{r}45 \\
25 \\
17 \\
19 \\
18 \\
8 \\
12 \\
11 \\
7 \\
4 \\
4 \\
2 \\
\star \\
2\end{array}$ & $\begin{array}{r}31 \\
23 \\
22 \\
16 \\
16 \\
12 \\
10 \\
7 \\
3 \\
4 \\
3 \\
3 \\
1 \\
2\end{array}$ & $\begin{array}{r}47 \\
7 \\
4 \\
21 \\
11 \\
22 \\
7 \\
3 \\
8 \\
1 \\
3 \\
- \\
-3\end{array}$ & $\begin{array}{r}30 \\
-- \\
6 \\
11 \\
8 \\
16 \\
7 \\
4 \\
4 \\
2 \\
1 \\
-- \\
2 \\
--\end{array}$ & $\begin{array}{c}1 \\
2 \\
5 \\
3 \\
4 \\
8 \\
6 \\
7 \\
9 \\
10.5 \\
10.5 \\
12.5 \\
14 \\
12.5\end{array}$ & $\begin{array}{c}1 \\
2 \\
3 \\
4.5 \\
4.5 \\
6 \\
7 \\
8 \\
11 \\
9 \\
11 \\
11 \\
14 \\
13\end{array}$ & $\begin{array}{c}1 \\
6.5 \\
8 \\
3 \\
4 \\
2 \\
6.5 \\
10 \\
5 \\
12 \\
10 \\
13.5 \\
10 \\
13.5\end{array}$ & $\begin{array}{c}1 \\
13 \\
6 \\
3 \\
4 \\
2 \\
5 \\
7.5 \\
7.5 \\
9.5 \\
11 \\
13 \\
9.5 \\
13\end{array}$ & $\begin{array}{r}37 \\
20 \\
17 \\
17 \\
16 \\
12 \\
10 \\
8 \\
5 \\
3 \\
3 \\
2 \\
1 \\
1\end{array}$ & $\begin{array}{l}1 \\
2 \\
3.5 \\
3.5 \\
5 \\
6 \\
7 \\
8 \\
9 \\
10.5 \\
10.5 \\
12 \\
13.5 \\
13.5\end{array}$ \\
\hline
\end{tabular}

- = no frequency

$\star=0.5 \%$, or less 
Table 4: Per Cent of All. Residents Who Saw Lawyer About Fourteen Types of Legal. Problems by Social Background Variables: Weighted Sample of Detroit SMSA, 1967.

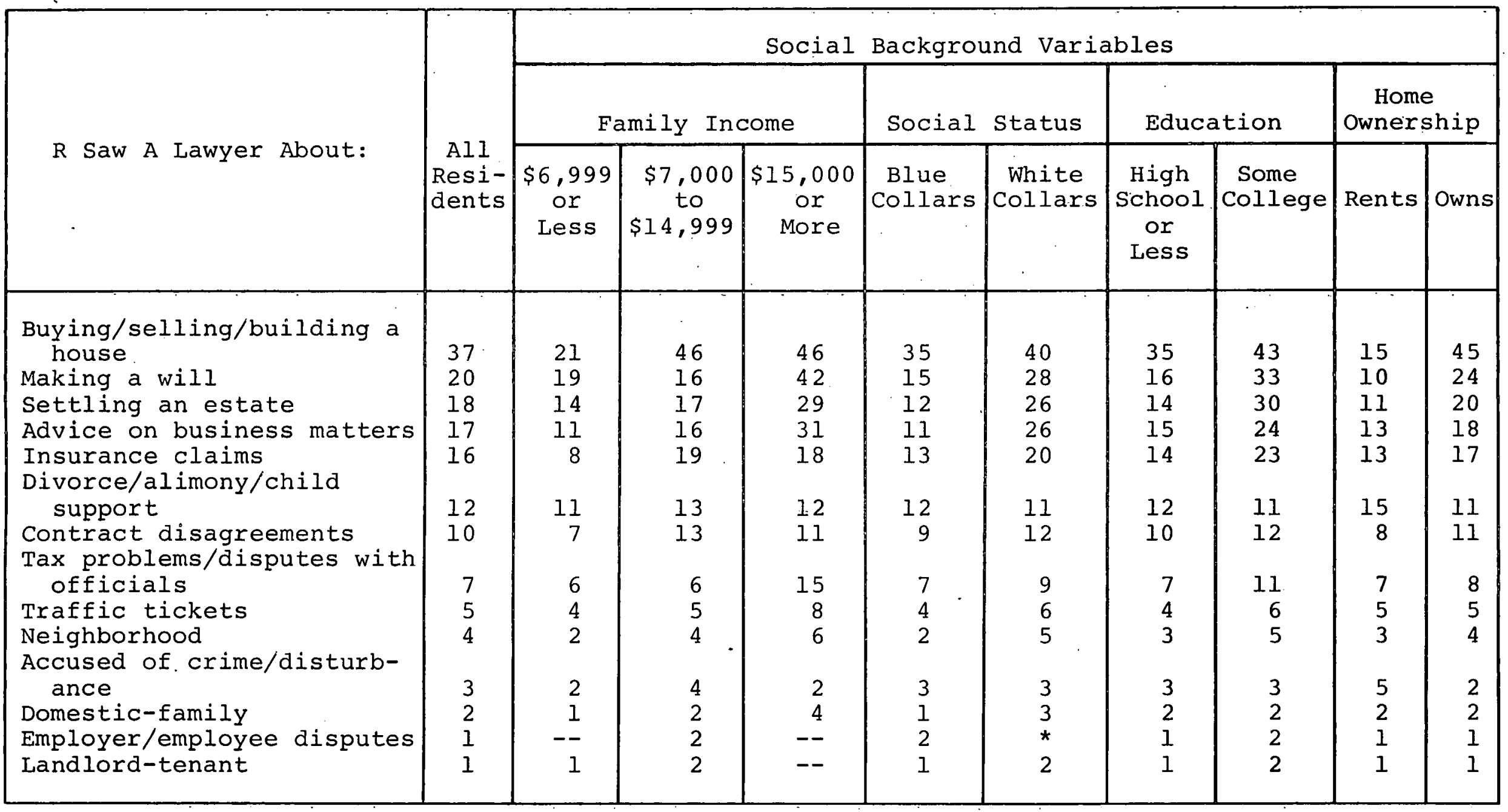

CONTINUED 
Table 4: Per Cent of All Residents Who Saw Lawyer About Fourteen Types of Legal Problems by Social Background Variables: Weighted Sample of Detroit SMSA, 1967. (CONT.)

\begin{tabular}{|c|c|c|c|c|c|c|}
\hline \multirow{3}{*}{ R Saw A Lawyer About: } & \multicolumn{6}{|c|}{ Social Background Variables } \\
\hline & \multicolumn{3}{|c|}{ Age } & \multicolumn{3}{|c|}{ Religion } \\
\hline & $\begin{array}{l}\text { Less than } \\
35 \text { Years }\end{array}$ & $\begin{array}{l}35-54 \\
\text { Years }\end{array}$ & $\begin{array}{l}55 \text { Years } \\
\text { and Older }\end{array}$ & Protestant & Catholic & Jewish \\
\hline $\begin{array}{l}\text { Buying/selling/building a } \\
\text { house } \\
\text { Making a will } \\
\text { Settling an estate } \\
\text { Advice on business matters } \\
\text { Insurance claims } \\
\text { Divorce/alimony/child } \\
\text { support } \\
\text { Contract disagreements } \\
\text { Tax problems/disputes with } \\
\text { officials } \\
\text { Traffic tickets } \\
\text { Neighborhood } \\
\text { Accused of crime/disturb- } \\
\text { ance } \\
\text { Domestic-family } \\
\text { Employer/employee disputes } \\
\text { Landlord-tenant }\end{array}$ & $\begin{array}{r}30 \\
9 \\
7 \\
13 \\
18 \\
14 \\
14 \\
7 \\
4 \\
5 \\
\\
5 \\
4 \\
3 \\
2\end{array}$ & $\begin{array}{l}43 \\
16 \\
18 \\
19 \\
18 \\
13 \\
11 \\
9 \\
6 \\
3 \\
3 \\
2 \\
1 \\
1\end{array}$ & $\begin{array}{r}36 \\
35 \\
25 \\
17 \\
10 \\
9 \\
7 \\
8 \\
4 \\
3 \\
1 \\
\star \\
-- \\
2\end{array}$ & $\begin{array}{l}36 \\
19 \\
15 \\
18 \\
13 \\
\\
14 \\
11 \\
9 \\
4 \\
3 \\
4 \\
2 \\
1 \\
1\end{array}$ & $\begin{array}{r}39 \\
22 \\
22 \\
15 \\
19 \\
\\
8 \\
10 \\
\\
6 \\
7 \\
3 \\
\\
2 \\
3 \\
2 \\
1\end{array}$ & $\begin{array}{r}56 \\
32 \\
24 \\
12 \\
32 \\
20 \\
8 \\
8 \\
-- \\
-- \\
-- \\
-- \\
-- \\
4\end{array}$ \\
\hline
\end{tabular}


Table 5: Number of Citizens Reporting Legal Problem As Serious and Per Cent Distribution of Citizens Considering Legal Problem As Serious, Per Cent of Problems for Which Legal Advice Was Sought, for Race-Sex Groups: Weighted Sample of Detroit SMSA, 1967.

\begin{tabular}{|c|c|c|c|c|c|c|c|c|c|c|c|c|c|c|c|c|c|c|}
\hline \multirow{3}{*}{$\begin{array}{l}\text { Type of Legal } \\
\text { Problem }\end{array}$} & \multicolumn{6}{|c|}{$\begin{array}{l}\text { Number of Citizens } \\
\text { With Serious Legal } \\
\text { Problems }\end{array}$} & \multicolumn{6}{|c|}{$\begin{array}{c}\text { Per Cent of Citizens } \\
\text { Reporting Problem As } \\
\text { Serious }\end{array}$} & \multicolumn{6}{|c|}{$\begin{array}{l}\text { Per Cent of Serious } \\
\text { Problems Where Legal } \\
\text { Advice Was Sought }\end{array}$} \\
\hline & \multicolumn{3}{|c|}{ White } & \multicolumn{3}{|c|}{ Negro } & \multicolumn{3}{|c|}{ White } & \multicolumn{3}{|c|}{ Negro } & \multicolumn{3}{|c|}{ White } & \multicolumn{3}{|c|}{ Negro } \\
\hline & Male & $\begin{array}{l}\mathrm{Fe}- \\
\text { male }\end{array}$ & $\begin{array}{l}\text { To- } \\
\text { tal }\end{array}$ & Male & $\begin{array}{l}\mathrm{Fe}- \\
\text { male }\end{array}$ & $\begin{array}{l}\text { To- } \\
\text { tal }\end{array}$ & Male & $\begin{array}{l}\mathrm{Fe}- \\
\text { male }\end{array}$ & $\begin{array}{l}\text { To- } \\
\text { tal }\end{array}$ & Male & $\begin{array}{l}\mathrm{Fe}- \\
\text { male }\end{array}$ & $\begin{array}{l}\text { To- } \\
\text { tal }\end{array}$ & Male & $\begin{array}{l}\mathrm{Fe}- \\
\text { male }\end{array}$ & $\mid \begin{array}{l}\text { To- } \\
\text { tal }\end{array}$ & Male & $\begin{array}{l}\mathrm{Fe}- \\
\text { male }\end{array}$ & $\begin{array}{l}\text { To- } \\
\text { tal }\end{array}$ \\
\hline $\begin{array}{l}\text { Neighborhood } \\
\text { Landlord-tenant } \\
\text { Purchase of ex- } \\
\text { pensive object } \\
\text { Public organiza- } \\
\text { tion } \\
\text { Discrimination }\end{array}$ & $\begin{array}{r}169 \\
19 \\
172 \\
112 \\
29\end{array}$ & $\begin{array}{r}195 \\
43 \\
178 \\
\\
98 \\
39\end{array}$ & $\begin{array}{r}364 \\
62 \\
350 \\
210 \\
68\end{array}$ & $\begin{array}{r}18 \\
9 \\
22 \\
12 \\
23\end{array}$ & $\begin{array}{l}40 \\
19 \\
26 \\
19 \\
19\end{array}$ & $\begin{array}{l}58 \\
28 \\
48 \\
31 \\
42\end{array}$ & $\begin{array}{r}53 \\
6 \\
54 \\
35 \\
9\end{array}$ & $\begin{array}{l}55 \\
12 \\
50 \\
\\
28 \\
11\end{array}$ & $\begin{array}{r}54 \\
9 \\
52 \\
31 \\
10\end{array}$ & $\begin{array}{l}35 \\
18 \\
43 \\
24 \\
45\end{array}$ & $\begin{array}{l}50 \\
24 \\
32 \\
\\
24 \\
24\end{array}$ & $\begin{array}{l}44 \\
21 \\
37 \\
24 \\
32\end{array}$ & $\begin{array}{r}8 \\
5 \\
17 \\
12 \\
10\end{array}$ & $\begin{array}{r}6 \\
5 \\
10 \\
8 \\
--\end{array}$ & $\begin{array}{r}7 \\
5 \\
13 \\
10 \\
4\end{array}$ & $\begin{array}{r}6 \\
11 \\
9 \\
17 \\
4\end{array}$ & $\begin{array}{r}5 \\
-- \\
12 \\
21 \\
10\end{array}$ & $\begin{array}{r}5 \\
4 \\
10 \\
19 \\
7\end{array}$ \\
\hline Total Number & 501 & 553 & 1054 & 84 & 123 & 207 & & & & $\because$ & & & & & & & & \\
\hline Total Per Cent & & & & & & & 82 & 76 & 79 & 72 & 74 & 73 & 12 & 7 & 9 & 8 & 9 & 9 \\
\hline
\end{tabular}

- = no frequency 


\section{FOOTNOTES}

1. Carlin and Howard examined studies from California, Texas, Iowa, Missouri, and Ohio and concluded that roughly two-thirds of upper income groups and one-third of lower income groups had ever employed the services of a lawyer.

2. Of course, one may not assume that the quality of representation is equal for all who use legal services. Indeed, the fact of stratification in the legal profession suggests the opposite. 
REFERENCES

Carlin, Jerome E.

1962 Lawyers on Their Own. New Brunswick, N.J.: Rutgers University Press.

1966 Lawyer's Ethics. New York: The Russell Sage Foundation.

Carlin, Jerome E. and Howard, Jan

1965 "Legal Representation and Class Justice."

UCLA Law Review 12 (January): 381-437.

Conard, Alfred E., et al.

1964 Automobile Accident Costs and Payments. Ann Arbor: University of Michigan Press.

Mayhew, Leon

1968a Law and Equal Opportunity. Cambridge, Mass.: Harvard University Press.

1968b "Action Theory and Action Research." Social Problems 15 (Spring): 420-432.

Reich, Charles

1963 "The New Property." Yale Law Journal 73. 
WORKING PAPERS OF THE

CENTER FOR RESEARCH ON SOCIAL ORGANIZATION

\author{
DEPARTMENT OF SOCIOLOGY \\ UNIVERSITY OF MICHIGAN
}

Papeṛ \#40

April, 1968

Copies Available Through:

Center for Research on Social Organization University of. Michigan 219 Perry Building 330 . Packard Street Ann Arbor, Michigan 48104 


\title{
THE SOCIAL ORGANIZATION OF LEGAL CONTACTS*
}

\section{by}

\author{
Leon Mayhew and Albert J. Reiss, Jr. \\ Center for Research on Social Organization \\ University of Michigan
}

* Being a paper presented at the annual meetings of the Midwest Sociological Association, Omaha, Nebraska, April 19, 1968. 


\section{THE SOCIAL ORGANIZATION OF LEGAL CONTACTS}

Everyone from time to time defines his affairs as legal matters or experiences violations of his legal rights. Yet little is known of how citizen affairs come to the attention of attorneys or official legal agencies. Particularly lacking is an understanding of how both the organization of citizen-affairs and of the legal system leads citizens to define affairs as legal matters and to seek advice from a lawyer. This paper presents some findings on problems citizens define as legal matters and their contact with attorneys. To prevent confusion and to forestall inappropriate criticism, we should also stress what the study is not. It is not, as are a number of recent studies, an attempt to assess the 'objective' legal requirements of: a population from a, value or organized system perspective. Rather it is based entirely on citizen reports of perceived problems and of their actual experience in problem solving, including contact:-with lawyers.

The findings result from a sample survey of the problems and legal experiences of 780 residents of the Detroit Metropolitan Area. The probability of selecting a Detroit City resident was set at twice that of a resident outside the central city so as to insure the inclusion of more Negro citizens in controlled analyses. All estimates of proportions, therefore; are based on a weighted sample of 1038 residents. 


\section{The Prevalence of Seeking Legal Advice or Help}

Each resident was asked whether they had ever gone to a lawyer or talked with a lawyer in order to get help or advice on problems that can be legal matters. Approximately 7 of every 10 residents in the weighted sample reported seeing a lawyer about a legal matter at least once in their life. One in four reported seeing a lawyer in the past year and almost one in two had seen a lawyer in the last five years. The actual hiring of lawyers is overestimated somewhat by these proportions since after seeing a lawyer the citizen in some instances decided that he could not afford his services. Contact with lawyers nevertheless is a prevalent experience among Detroit area residents. Indeed, inspection of Table 1 shows that for all major race, sex, age, and socioeconomic status groups, contact with attorneys is higher than is commonly supposed. In the socioeconomic status group with least contact with attorneys--Negro females with a family income of less than $\$ 7,000$ a year--40 per cent reported seeing a lawyer about a legal problem.

Despite the high prevalence of contact with lawyers for all structural status groups shown in Table 1 , contact. with a lawyer does vary with status. It might be objected that ever having seen a lawyer is a very weak index of legal contact since one visit to an attorney places a person among the "haves". Preliminary analysis indicates that stronger indicators of legal contact such as seeing a lawyer about three or more separate types of incidents does not increase the 
differences in the legal experience of socioeconomic status groups,

The best predictors of contact with attorneys are family income and property as is indicated by the consistent and substantial differences between income and home ownership groups for all respondents even when race and sex are controlled. Among respondents with annual family income of over $\$ 15,000,83$ per cent reported seeing a lawyer as compared to 56 per cent among persons with an income less than $\$ 7,000$. Education, occupational status, age, and sex have a moderate to strong effect but neither variable is as discriminating as family income or home ownership.

On first glance race appears to have a substantial effect. Fifty-nine per cent of Negroes and 71 per cent of whites said they saw a lawyer about a legal matter. closer scrutiny indicates that this difference is largely accounted for by the asymmetric position of Negro females who saw lawyers less frequently than either Negro males or white females. Negro males, despite the facts of low income and education, report nearly as much contact with attorneys as their white counterparts. On the other hand, Negro males are also more likely to report that they have been "cooled out" during a visit to an attorney. Seventeen per cent of Negro males said that they had been discouraged from taking legal action by an attorney. The comparable figure for white males is only 7 per cent. These socioeconomic differences in the use of legal services are consistent with differences found in studies 
of other cities. $\underline{l}$

Social Organization and Contact with Attorneys

The oft reported finding of a relationship between income. and the use of professional legal services suggests a measure of validity for a simple "resources" theory of legal representation. According to this theory those who have resources such as income, and to a lesser extent other resources such as education and social connections, are more likely to perceive the need for, afford, and gain access to legal services. Resources, therefore, account for the distribution of the use of lawyers in the population.

That resources make a difference is even more clearly supported by the association between income and using attorneys within-populations who have experienced a given legal problem. Conard et. al, for example, report a strong association between. income and legal representation among a sample of persons who have been injured in automobile accidents. $\underline{2}$.

Nevertheless, the resources theory fails to account for the extent of use of. legal services even among those with the least resources. More seriously, the resources theory does not predict the differences in the pattern of use of legal services across socioeconomic categories. Access to resources is not a sufficient explanation of the patterns of contact between attorneys and the public for attorney-client relations occur in the context of a complicated network of social organization. 
We know from a series of studies of the legal profession that legal practice is both specialized.and stratified. The stratification of access to resources in the population parallel this differentiation and stratification of legal practice. The demand for legal services produces a response from competitive lawyers who move in to fill vacant niches so that distinctive patterns of practice emerge in various problem areas, e.g. estate, tax, criminal, contract, etc. $\underline{3}$ The response may be inadequate from the point of view of public policy but it is nonetheless a response. Specialization and stratification of legal practice accordingly mitigate the relation between resources and access to attorneys. We also observe a set of:distinctive patterns of use of legal services which reflects variations in the patterns of problems experienced in various structural locations such as communities or race and ethnic groups and corresponding differences in the social organization of activity and not differences in resources. Tables 2 and 3 show bṛeakdowns by socioeconomic background variables of the types of problems our sample took to lawyers. Although there is a rough similarity in the distribution of legal problems across all socioeconomic categories, a number of remarkable differences are also demonstrated.

One of the most striking differences is the racial variation in seeing. lawyers about the related areas of family affairs and property. A large proportion of the sample are home owners, a fact reflecting the prevalence of home ownership in the Detroit area. Seventy-seven per cent of white 
respondents and 51 per cent of Negro respondents are home owners. Home ownership clearly has brought Negroes into contact with the legal profession; 36 per cent of Negroes have seen a lawyer about buying a home, a figure virtually identical to the 37 per cent of. whites who have seen a lawyer for this purpose. But this introduction to the property complex has not yet become sufficiently institutionalized to fully incorporate Negroes into the organized system by which property is passed on. Only 3 per cent of Negroes had seen a lawyer about making a will. Among whites this is the second most common occasion for visiting a lawyer, as 23 per cent have seen a lawyer about making a will.

Seeing a lawyer about a will is not viewed as a pressing legal problem among Negroes. In response to the query "Have you ever. wanted to go to a lawyer but didn't for some reason?" Negroes and whites answered "Yes" in approximately equal proportions, 19 per cent among whites and 17 per cent among Negroes. Yet only one. Negro informant mentioned a will in this regard. By contrast, 35 per cent of the problems of whites who wanted to talk to a lawyer but didn't involved wills. That the passing on of property is less embedded in a legal context among Negroes is also indicated from the fact that 20 per cent of whites and only. 5 per cent of Negroes had seen a lawyer about settling an estate.

These differences by race status in the use of legal advice to handle personal property parallel rather closely the Negro's integration into American Society. Consider 
institutionalized cycle of personal property where legal advice pertains first in its acquisition, then in respect to its sale, transformation, or taxation, followed by advice on disposition in the event of the death of its owner, and concluding with the settling of an estate. It seems clear that the Negro in major metropolitan areas such as Detroit is institutionally integrated in seeking legal advice for the acquisition of personal property and has organized access to legal resources for that end. Given the recency of the acquisition, there is less integration with respect to other phases of the personal property cycle.

Nonetheless, given the high rate of acquisition of personal property among Negroes, particularly in the form of housing, one. would forecast that Negroes will. increasingly. seek legal advice for other property matters as well, although perhaps at a lesser rate. Some indication of this can be gained from the fact that the only Negroes in the sample to have seen a. lawyer about making a will were Negro males aged 55 and older. Twenty-six per cent of these Negro males as compared with 35 per cent of white females and 41 per cent of white males of this age had seen a lawyer about making a will.

The incomplete involvement of Negroes in the property complex may also be related to the much noted instability of Negro family structure. This is suggested not only from the fact just cited--that only older Negro males make wills--but from the prevalence among Negroes of seeing lawyers about divorces, alimony, and child support. We can see from Table 2 
that among Negroes this type of problem is the second most common occasion for seeing a lawyer with 18 per cent having been to a lawyer in this connection. Among whites the problem ranks seventh at 10 per cent.

It is worth noting in passing that this problem area of divorce, alimony, and child support is the only major area where the incidence of seeing a lawyer shows no relation to either income, occupational status, or education. Seeing a lawyer about a disagreement about a contract or purchase also shows only a weak relation to these variables but within the other major categories of problems there is a strong relationship between socioeconomic status and contact with attorneys. For all major categories of legal problems other than divorce and related matters, Negroes have had somewhat less contact with attorneys than whites. However, as mentioned. before, Negro females account for much of the race difference. Comparing only Negro males to white males we find that Negro males are more likely to have seen a lawyer about buying, selling, or building a house, about advice in business matters, about traffic tickets, about disputes with employers and about divorce, alimony and child support although except in the case of divorce, the differences are quite small. In view of the fact that our Negro males have much less income on the average than the white males, we can conclude that the Negro male participates in a number of organized systems that bring him into contact with lawyers more than might be expected on the basis of income. Looking at middle income 
$(\$ 7,000$ to $\$ 14,999)$ males, for example, we find that 23 per cent of Negroes and only 8 per cent of whites have seen a lawyer about a divorce or a related matter. On the other hand the greater proportion of whites who have seen a lawyer about making a will or settling an estate hold up even when income is introduced as a control. Looking only at low income males $(\$ 6,999$ and less), we find that 27 per cent of whites and 8 per cent of Negroes had seen a lawyer about a will and 10 per cent of whites and 8 per cent of Negroes had seen a lawyer about settling an estate. Among middle income males $(\$ 7,000$ to $\$ 14,999)$ the corresponding figures are 19 per cent of whites and 5 per cent of Negroes in regard to a will and 17 per cent of whites and 2 per cent of Negroes in regard to settling an estate. In short, income differences are important in determining access to attorneys, but differences in patterns of participation in social organization, particularly the social organization of property and familial relations, also affect the patterns of contact between citizens and attorneys.

\section{Seeing A Lawyer: Rates and Incidence}

The preceeding data refer primarily to the incidence of seeing lawyers about various types of legal problems. To compute a rate we would need to know what proportion of the sample had experienced a given type of legal problem and then what proportion of that group had seen a lawyer about it. In some contexts this is a less serious problem than in others. 
Thus, in a sense everyone has a problem in connection with making a will since, though some estates are smail; everyone owns something and, though: some are young, everyone will ultimately die. Further in some cases we have rough denominators for rates because we know who are now home owners, we are led to believe that the rate of consulting attorneys is higher for Negroes than whites. Holding sex and income constant, Negroes are as likely to have seen a lawyer about buying a home even though fewer Negroes are home owners. Other matters such as accidents can be assumed to be relatively evenly distributed across socioeconomic categories. Nevertheless, in some categories, disputes with government agencies and tax problems for example, it is more difficult to estimate an appropriate denominator for computing a rate. The problem is exacerbated by the fact that the more one strives for comparability of problems through applying restrictive definitions to various types of problems, the smaller becomes the number of persons who have had that particular type of problem and, in some cases, the number who have seen a lawyer about that precise problem becomes too small to study.

At one point in our interview we attempted to generate case histories about the respondents most serious problems. First we took an inventory of the informants problems in five areas--relations in the neighborhood, landlord-tenant relations, relations with the sellers of expensive objects, relations with public organizations, and discrimination because of race; sex, age, religion, nationality, or beliefs. Then we asked for 
detailed histories of the two problems which were considered by the respondent to have been the most serious or to have caused the most problems. For both most serious and second most serious problems considered separately about 9 per cent reported seeing a lawyer about the problem. Table 4 combines the most serious and second most serious problems and breaks them down by race and sex, and by type of problem indicating the per cent who saw a lawyer. Few gross differences by race status are apparent in this table. One difference merits brief attention since it illustrates differences that may emerge when rates rather than incidences are made the focus of study. Negroes are apparently more likely to visit lawyers when they face serious trouble with public organizations. The percentage who saw a lawyer among those who chose problems with public organizations as one of their two most serious problems is 19 per cent for Negroes and 10 per cent for whites. Yet the corresponding incidence figures for seeing a lawyer about a problem with public organizations (including police) appears to be higher for whites than for Negroes. In other words, whites are more likely to see lawyers about problems in relation to government but Negroes appear to be more likely to see lawyers about their most serious problems with government authority. Beyond merely illustrating differences that emerge from variable ways of expressing degrees of contact with the legal profession; this difference reinforces an organizational interpretation of patterns of contact. 
Mere differences in access to resources cannot account for patterns of access to attorneys in regard to problems of public authority. Citizens at different income levels in different structural locations experience different types of problems and are connected to government in different ways. Accordingly they have different probabilities of becoming involved with attorneys in relation to government authority. Thus, Negro citizens report fewer difficult problems in relation to government but their serious problems with government are more likely to be with police and with welfare agencies and to require legal aid. White citizens report more problems with public organizations and more contact with attorneys about public organizations, but their worst problems concern taxes and government services rather than police and welfare agencies. Their most serious problems with public authority do not seem to have the same capacity to draw them into contact with attorneys.

In sum, income and location in the social structure may affect contact with attorneys not only through providing relevant resources but by determining what types of problems people have. Each problem has its own patterns of constraints and requirements for the use of legal services. Citizens are not brought into contact with the legal profession merely by their resources but by their problems, institutionalized definitions, and the social organization of problem solution. 
1. For a review of relevant literature on income, social status and use of legal services see Jerome E. Carlin and Jan Howard "Legal Representation and Class Justice" 12 UCLA Law Review 381 (1965).

2. Alfred F. Conard et al "Automobile Accidents Costs and Payments, Ann Arbor; The University of Michigan Press, 1964 pp. 225-227.

3. Jerome E. Carlin, Lawyers on Their Own New Brunswick, N.J.: Rutgers University press 1962 and Jerome E. Carlin, Lawyer's Ethics New York: Russell Sage Foundation, 1966 are two very relevant studies. Of course we may not assume that the quality of representation is equal for all who use legal services. Indeed, the fact of stratification in the legal profession suggests the opposite. 
Table 1: Per Cent of All Residents Who Sought Advice From A Lawyer by Social Background Factors: Weighted Sample of Detroit. SMSA, 1967.

\begin{tabular}{|c|c|c|c|c|c|}
\hline $\begin{array}{l}\text { Social } \\
\text { Background } \\
\text { Factors }\end{array}$ & $\begin{array}{c}\text { Per Cent } \\
\text { Seeking } \\
\text { Advice } \\
\text { from Lawyer }\end{array}$ & $\begin{array}{c}\text { Social } \\
\text { Background } \\
\text { by Race } \\
\text { and Sex }\end{array}$ & $\begin{array}{c}\text { Per Cent } \\
\text { Seeking } \\
\text { Advice } \\
\text { from Lawyer }\end{array}$ & $\begin{array}{l}\text { Social } \\
\text { Background } \\
\text { by Race } \\
\text { and Sex }\end{array}$ & $\begin{array}{c}\text { Per Cent } \\
\text { Seeking } \\
\text { Advice } \\
\text { from Lawyer }\end{array}$ \\
\hline $\begin{array}{l}\text { Race: } \\
\text { White } \\
\text { Negro. } \\
\text { Sex: } \\
\text { Male } \\
\text { Female } \\
\text { Race-Sex: } \\
\text { White male } \\
\text { White female } \\
\text { Negro male } \\
\text { Negro female } \\
\text { Home Ownership: } \\
\text { Owner } \\
\text { Renter } \\
\text { Religion: } \\
\begin{array}{l}\text { Catholic } \\
\text { Protestant } \\
\text { Jewish }\end{array}\end{array}$ & $\begin{array}{l}71 \\
59 \\
\\
73 \\
66\end{array}$ & $\begin{array}{l}\text { Race-Sex-Income: } \\
\text { White male } \\
\$ 6,999 \text { or less } \\
\$ 7,000-\$ 14,999 \\
\$ 15,000 \& \text { over } \\
\text { White female } \\
\$ 6,999 \text { or less } \\
\$ 7,000-\$ 14,999 \\
\$ 15,000 \& \text { over } \\
\text { Negro male } \\
\$ 6,999 \text { or less } \\
\$ 7,000-\$ 14,999 \\
\$ 15,000 \& \text { over } \\
\text { Negro female: } \\
\$ 6,999 \text { or less } \\
\$ 7,000-\$ 14,999 \\
\$ 15,000 \text { \& over }\end{array}$ & $\begin{array}{l}59 \\
78 \\
84 \\
\\
61 \\
71 \\
83 \\
\\
58 \\
72 \\
* \\
\\
40 \\
82 \\
\text { * }\end{array}$ & $\begin{array}{l}\text { Race-Sex-Education: } \\
\text { White male } \\
\text { High school or less } \\
\text { Some college } \\
\text { White female } \\
\text { High school or less } \\
\text { Some college } \\
\text { Negro male } \\
\text { High school or less } \\
\text { Some college } \\
\text { Negro female } \\
\text { High school or less } \\
\text { Some college }\end{array}$ & $\begin{array}{r}71 \\
82 \\
\\
67 \\
75 \\
\\
69 \\
\star\end{array}$ \\
\hline
\end{tabular}


Table 1:. Per Cent of All Residents who Sought Advice From: A Lawyer by Social Background Factors: Weighted Sample of Detroit SMSA, 1967.'(CONTINUED)

\begin{tabular}{|c|c|c|c|c|c|}
\hline $\begin{array}{c}\text { Social } \\
\text { Background } \\
\text { Factors }\end{array}$ & $\begin{array}{c}\text { Per Cent } \\
\text { Seeking } \\
\text { Advice } \\
\text { from Lawyer }\end{array}$ & $\begin{array}{c}\text { Social } \\
\text { Background } \\
\text { by Race } \\
\text { and Sex }\end{array}$ & $\begin{array}{l}\text { Per Cent } \\
\text { Seeking } \\
\text { from Lawyer. }\end{array}$ & $\begin{array}{l}\text { Social } \\
\text { Background } \\
\text { by Race } \\
\text { and Sex }\end{array}$ & $\begin{array}{c}\text { Per Cent } \\
\text { Seeking } \\
\text { Advice } \\
\text { from Lawyer }\end{array}$ \\
\hline $\begin{array}{l}\text { Age: } \\
\text { Under } 35 \\
35-54 \\
55 \cdot \text { and over } \\
\text { Income: } \\
\$ 6,999 \text { or less } \\
\$ 7,000-\$ 14,999 \\
\$ 15,000 \& \text { over. } \\
\text { Education: } \\
\text { High school or less } \\
\text { Some college ? } \\
\text { Social Status: } \\
\text { White collar } \\
\text { Blue collar } \\
\text { All residents }\end{array}$ & $\begin{array}{r}65 \\
73 \\
69 \\
\\
\\
\\
56 \\
74 \\
83 \\
\\
\\
67 \\
77\end{array}$ & $\begin{array}{l}\text { Race-Sex-Social } \\
\text { Status: } \\
\text { White male } \\
\text { White collar } \\
\text { Blue collar } \\
\text { White female } \\
\text { White collar } \\
\text { Blue collar } \\
\text { Negro male } \\
\text { White collar } \\
\text { Blue collar. } \\
\text { Negro female } \\
\text { White collar } \\
\text { Blue collar. }\end{array}$ & $\begin{array}{l}79 \\
70 \\
\\
72 \\
67\end{array}$ & $\begin{array}{l}\text { Race-Sex-Home Owner- } \\
\text { ship: } \\
\text { White male } \\
\text { Owns } \\
\text { Rents } \\
\text { White female } \\
\text { Owns } \\
\text { Rents } \\
\text { Negro male } \\
\text { Owns } \\
\text { Rents } \\
\text { Negro female } \\
\text { Owns } \\
\text { Rents }\end{array}$ & $\begin{array}{l}77 \\
64 \\
\\
76 \\
46 \\
\\
72 \\
66 \\
\\
71 \\
36\end{array}$ \\
\hline
\end{tabular}


Table 2:' Per Cent of All Residents Who Saw Lawyer by Fourteen Types of Legal Problems and Rank Order of These Per Cents, by Race and Sex of Respondent: Weighted Sample of Detroit SMSA, 1967.

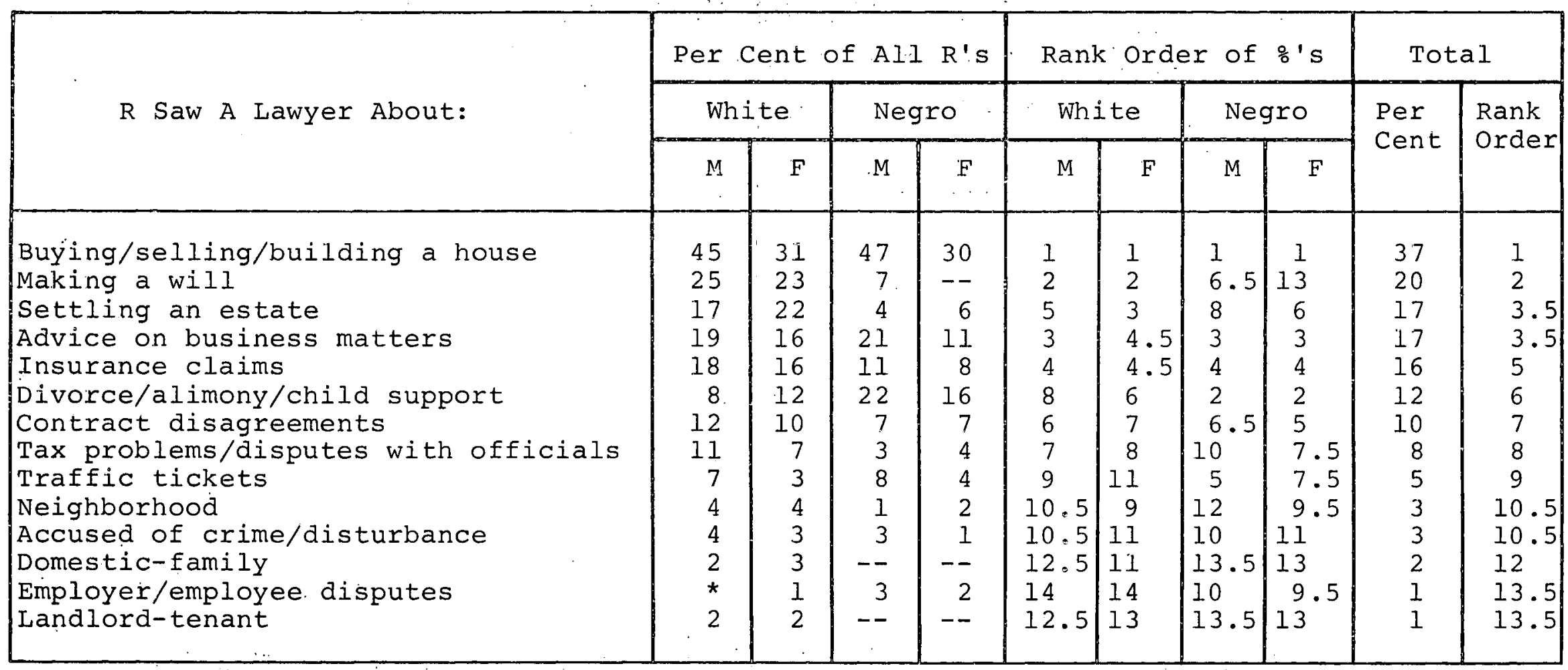

$$
\begin{aligned}
& -={ }_{i} \text { no Erequency } \\
& *=0.5 \%, \text { or less }
\end{aligned}
$$


Table 3: Per Cent of All Residents. Who Saw. Lawyer About Fourteen Types of Legal Problems by Social Background Variables: Weighted Sample of Detroit SMSA, 1967.

\begin{tabular}{|c|c|c|c|c|c|c|c|c|c|c|}
\hline \multirow{3}{*}{ R Saw A Lawyer About: } & \multirow[b]{3}{*}{$\begin{array}{c}\text { All } \\
\text { Resi- } \\
\text { dents }\end{array}$} & \multicolumn{9}{|c|}{ Social Background Variables } \\
\hline & & \multicolumn{3}{|c|}{ Family Income } & \multicolumn{2}{|c|}{ Social Status. } & \multicolumn{2}{|c|}{ Education. } & \multicolumn{2}{|c|}{$\begin{array}{c}\text { Home } \\
\text { Ownership }\end{array}$} \\
\hline & & $\begin{array}{c}\$ 6,999 \\
\text { or } \\
\text { Less }\end{array}$ & $\begin{array}{c}\$ 7,000 \\
\text { to } \\
\$ 14,999\end{array}$ & $\begin{array}{c}\$ 15,000 \\
\text { or } \\
\text { More }\end{array}$ & $\mid \begin{array}{c}\text { Blue } \\
\text { Collars }\end{array}$ & $\begin{array}{l}\text { White } \\
\text { Collars }\end{array}$ & $\begin{array}{c}\text { High } \\
\text { School } \\
\text { or } \\
\text { Less }\end{array}$ & $\begin{array}{c}\text { Some } \\
\text { College }\end{array}$ & Rents & Owns \\
\hline $\begin{array}{l}\text { Buying/selling/building a } \\
\text { house } \\
\text { Making a will. } \\
\text { Settling an estate } \\
\text { Advice on business matters } \\
\text { Insurance claims } \\
\text { Divorce/alimony/child } \\
\text { support } \\
\text { Contract disagreements } \\
\text { Tax problems/disputes with } \\
\text { officials } \\
\text { Traffic tickets } \\
\text { Neighborhood } \\
\text { Accused of crime/disturb- } \\
\text { ance } \\
\text { Domestic-family } \\
\text { Employer/employee disputes } \\
\text { Landlord-tenant }\end{array}$ & $\begin{array}{l}37 \\
20 \\
18 \\
17 \\
16 \\
12 \\
10 \\
7 \\
5 \\
4 \\
3 \\
2 \\
1 \\
1\end{array}$ & $\begin{array}{r}21 \\
19 \\
14 \\
11 \\
8 \\
11 \\
7 \\
6 \\
4 \\
2 \\
2 \\
1 \\
-- \\
1\end{array}$ & $\begin{array}{l}46 \\
16 \\
17 \\
16 \\
19 \\
13 \\
13 \\
6 \\
5 \\
4 \\
4 \\
2 \\
2 \\
2\end{array}$ & $\begin{array}{r}46 \\
42 \\
29 \\
31 \\
18 \\
12 \\
11 \\
15 \\
8 \\
6 \\
2 \\
4 \\
-- \\
--\end{array}$ & $\begin{array}{r}35 \\
15 \\
12 \\
11 \\
13 \\
12 \\
9 \\
7 \\
4 \\
2 \\
3 \\
1 \\
2 \\
1\end{array}$ & $\begin{array}{c}40 \\
28 \\
26 \\
26 \\
20 \\
11 \\
12 \\
9 \\
6 \\
5 \\
3 \\
3 \\
* \\
2\end{array}$ & $\begin{array}{l}35 \\
16 \\
14 \\
15 \\
14 \\
12 \\
10 \\
7 \\
4 \\
3 \\
3 \\
2 \\
1 \\
1\end{array}$ & $\begin{array}{r}43 \\
33 \\
30 \\
24 \\
23 \\
11 \\
12 \\
11 \\
6 \\
5 \\
3 \\
2 \\
2 \\
2\end{array}$ & $\begin{array}{r}15 \\
10 \\
11 \\
13 \\
13 \\
15 \\
8 \\
7 \\
5 \\
3 \\
5 \\
2 \\
1 \\
1\end{array}$ & $\begin{array}{l}45 \\
24 \\
20 \\
18 \\
17 \\
11 \\
11 \\
8 \\
5 \\
4\end{array}$ \\
\hline
\end{tabular}

CONTINUED 
Table 3: Per Cent of All Residents Who Saw Lawyer About Fourteen Types of Legal Problems by Social Background Variables: Weighted-Sample of Detroit SMSA, 1967 . (CONT.)

\begin{tabular}{|c|c|c|c|c|c|c|}
\hline \multirow{3}{*}{ R Saw A Lawyer About: } & \multicolumn{6}{|c|}{ Social Background Variables } \\
\hline & \multicolumn{3}{|c|}{ Age } & \multicolumn{3}{|c|}{ Religion } \\
\hline & $\begin{array}{l}\text { Less than } \\
35 \text { Years }\end{array}$ & $\begin{array}{l}35-54 \\
\text { Years }\end{array}$ & $\begin{array}{l}55 \text { Years } \\
\text { and Older }\end{array}$ & Protestant & Catholic & Jewish \\
\hline $\begin{array}{l}\text { Buying/selling/building a } \\
\text { house } \\
\text { Making a will } \\
\text { Settling an estate } \\
\text { Advice on business matters } \\
\text { Insurance claims } \\
\text { Divorce/alimony/child } \\
\text { support } \\
\text { Contract disagreements } \\
\text { Tax problems/disputes with } \\
\text { officials } \\
\text { Traffic tickets } \\
\text { Neighborhood } \\
\text { Accused of crime/disturb- } \\
\text { ance } \\
\text { Domestic-family } \\
\text { Employer/employee disputes } \\
\text { Landlord-tenant }\end{array}$ & $\begin{array}{r}30 \\
9 \\
7 \\
13 \\
18 \\
14 \\
14 \\
7 \\
4 \\
5 \\
5 \\
4 \\
3 \\
2\end{array}$ & $\begin{array}{l}43 \\
16 \\
18 \\
19 \\
18 \\
13 \\
11 \\
9 \\
6 \\
3 \\
3 \\
2 \\
1 \\
1\end{array}$ & $\begin{array}{r}36 \\
35 \\
25 \\
17 \\
10 \\
9 \\
7 \\
8 \\
4 \\
3 \\
\\
1 \\
\star \\
-- \\
2\end{array}$ & $\begin{array}{r}36 \\
19 \\
15 \\
18 \\
13 \\
14 \\
11 \\
9 \\
4 \\
3 \\
4 \\
2 \\
1 \\
1\end{array}$ & $\begin{array}{r}39 \\
22 \\
22 \\
15 \\
19 \\
\\
8 \\
10 \\
\\
6 \\
7 \\
3 \\
2 \\
3 \\
2 \\
1\end{array}$ & $\begin{array}{r}56 \\
32 \\
24 \\
12 \\
32 \\
20 \\
8 \\
\\
8 \\
-- \\
-- \\
-- \\
-- \\
-- \\
4\end{array}$ \\
\hline
\end{tabular}

$$
\begin{aligned}
& -=\text { no frequency } \\
& *=0.5 \%, \text { or less }
\end{aligned}
$$


Table 4: Number of Citizens Reporting Legal Problem As Serious and Per Cent Distribution of Citizens Considering Legal Problem As Serious; Per Cent of Problems for Which Legal Advice Was Sought, for Race-Sex Groups: Weighted Sample of Detroit. SMSA, 1967.

\begin{tabular}{|c|c|c|c|c|c|c|c|c|c|c|c|c|c|c|c|c|c|c|}
\hline \multirow{3}{*}{$\begin{array}{c}\text { Type of Legal } \\
\text { Problem }\end{array}$} & \multicolumn{6}{|c|}{$\begin{array}{l}\text { Number of Citizens } \\
\text { With Serious Legal } \\
\text { Problems }\end{array}$} & \multicolumn{6}{|c|}{$\begin{array}{l}\text { Per Cent of Citizens } \\
\text { Reporting Problem As } \\
\text { Serious }\end{array}$} & \multicolumn{6}{|c|}{$\begin{array}{l}\text { Per Cent of Seriou's } \\
\text { Problems Where Legal } \\
\text { Advice Was Sought }\end{array}$} \\
\hline & \multicolumn{3}{|c|}{ White } & \multicolumn{3}{|c|}{ Negro. } & \multicolumn{3}{|c|}{ White } & \multicolumn{3}{|c|}{ Negro } & \multicolumn{3}{|c|}{ White } & \multicolumn{3}{|c|}{ Negro } \\
\hline & Male & $\begin{array}{l}\mathrm{Fe}- \\
\text { male }\end{array}$ & $\begin{array}{l}\text { To- } \\
\text { tal }\end{array}$ & Male & $\begin{array}{l}\mathrm{Fe}- \\
\text { male }\end{array}$ & $\begin{array}{l}\text { To- } \\
\text { tal }\end{array}$ & Male & $\begin{array}{l}\mathrm{Fe}- \\
\text { male }\end{array}$ & $\begin{array}{l}\text { To- } \\
\text { tal }\end{array}$ & Male & $\begin{array}{l}\mathrm{Fe}- \\
\mathrm{male}\end{array}$ & $\begin{array}{l}\text { To- } \\
\text { tal }\end{array}$ & Male & $\begin{array}{l}\mathrm{Fe}- \\
\text { male }\end{array}$ & $\begin{array}{l}\text { To- } \\
\text { tal }\end{array}$ & Male & $\begin{array}{l}\text { Fe- } \\
\text { male }\end{array}$ & $\begin{array}{l}\text { To- } \\
\text { tal }\end{array}$ \\
\hline $\begin{array}{l}\text { Neighborhood } \\
\text { Landlord-tenant } \\
\text { Purchase of ex- } \\
\text { pensive object } \\
\text { Public organiza- } \\
\text { tion } \\
\text { Discrimination }\end{array}$ & $\begin{array}{r}169 \\
19 \\
172 \\
112 \\
29\end{array}$ & $\begin{array}{r}195 \\
43 \\
178 \\
98 \\
39\end{array}$ & $\begin{array}{r}364 \\
62 \\
350 \\
210 \\
68\end{array}$ & $\begin{array}{r}18 \\
9 \\
22 \\
12 \\
23\end{array}$ & $\begin{array}{l}40 \\
19 \\
26 \\
19 \\
19\end{array}$ & $\begin{array}{r}58 \\
28 \\
\\
48 \\
31 \\
42\end{array}$ & $\begin{array}{r}53 \\
6 \\
54 \\
35 \\
9\end{array}$ & $\begin{array}{l}55 \\
12 \\
50 \\
28 \\
11\end{array}$ & $\begin{array}{r}54 \\
9 \\
52 \\
31 \\
10\end{array}$ & $\begin{array}{l}35 \\
18 \\
43 \\
24 \\
45\end{array}$ & $\begin{array}{l}50 \\
24 \\
32 \\
\\
24 \\
24\end{array}$ & $\begin{array}{l}44 \\
21 \\
37 \\
24 \\
32\end{array}$ & $\begin{array}{r}8 \\
5 \\
17 \\
12 \\
10\end{array}$ & $\begin{array}{r}6 \\
5 \\
10 \\
8 \\
--\end{array}$ & $\begin{array}{r}7 \\
5 \\
13 \\
10 \\
4\end{array}$ & $\begin{array}{r}6 \\
11 \\
9 \\
17 \\
4\end{array}$ & $\begin{array}{r}5 \\
-- \\
12 \\
21 \\
10\end{array}$ & $\begin{array}{r}5 \\
4 \\
10 \\
19 \\
19\end{array}$ \\
\hline Total Number & 501 & 553 & 1054 & 84 & 123 & 207 & & & & & & & & & & & & \\
\hline Total Per Cent & & & & & & & 82 & 76 & 79 & 72 & 74 & 73 & 12 & 7 & 9 & 8 & 9 & 9 \\
\hline
\end{tabular}

